\title{
АНАЛІЗ ПРОБЛЕМИ ГОТОВНОСТІ ДО ДІЯЛЬНОСТІ У ПСИХОЛОГО-ПЕДАГОГІЧНІЙ ЛІТЕРАТУРІ
}

\begin{abstract}
Шульга А. В.Аналіз проблеми готовності до діяльності у психологопедагогічній літературі.

У статті розкривається поняття «готовність» як важливий складник психологічної діяльності людини, яка впливає на успішність виконання будь-якої діяльності та ефективне їі завершення. Поряд 3 поняттям готовність використовується таке поняття, як підготовленість і психологічна установка, однак ці поняття не $є$ тотожними. Розглядаються підходи до визначення поняття «психологічна готовність» та іiї форми.
\end{abstract}

Ключові слова: готовність, психологічна готовність, підготовленість, психологічна установка, готовність до дії, готовність до діяльності.

Шульга А. В. Анализ проблемы готовности к деятельности в психологопедагогической литературе.

В статье раскрывается понятие «готовность» как важная составляющая психологической деятельности человека, которая влияет на успешность выполнения любой деятельности и эффективное ее завершения. Наряду с понятием готовности также используется такое понятие, как подготовленность и психологическая установка, однако эти понятия не являются тождественными. Рассматриваются подходы к определению понятия «психологическая готовность» и ее формы.

Ключевые слова:готовность, психологическая готовность, подготовленность, психологическая установка, готовность к действию, готовность к деятельности.

Shulga A. V. Analysis of the problem preparedness activities in psychological and educational literature.

The paper reveals the concept of readiness as an important component of psychological human activities that count for any business and its effective completion. Along with the concept of readiness is also used as a concept preparedness and attitudes, but these concepts are not identical. Approaches to the definition of psychological readiness and its forms.

Keywords: readiness, psychological readiness, preparedness, attitudes, willingness to act, a willingness to work.

Готовність входить до низки основних структурних складників психічної діяльності людини. Психологічна готовність людини до діяльності, на думку Б. Паригіна, ніби акумулює в собі в згорнутому вигляді, подібно сильно стислій пружині, усі необхідні й достатні для успішного розв'язку поставленого завдання елементи майбутньої дії [5].

Готовність до діяльності $є$ обов'язковою умовою не тільки ії початку, але й ефективного завершення. Природно, що феномен психологічної готовності до дії й діяльності людини завжди привертав до себе увагу в тих випадках, коли йдеться про використання iї сил і можливостей у незвичайних, екстремальних умовах.

Склалася відповідно і практика формування спеціальної, зокрема й 
психологічної, готовності фахівця як чинника ефективної діяльності в екстремальних умовах. Така практика підготовки до діяльності спортсмена, військового льотчика, льотчика-випробувача, полярника або космонавта. Вона обов'язково передбачає як певну програму формування психологічноїготовності до майбутньої діяльності, так у низці випадків й оцінку рівня досягнутого результату.

Специфічною професійною діяльністю в екстремальних умовах проблема психологічної готовності не вичерпується. Не менш актуальною вона є в будь-якій професійній діяльності. Звідси значущість психологічного забезпечення професійного відбору й готовності кадрів. Але й очевидною $є$ необхідність психологічної готовності людини до життєдіяльності в цілому [5].

Уведення поняття готовності у психологію пов’язувалося 3 необхідністю визначення рівня можливостей людини до ефективного здійснення того чи того виду трудової діяльності. Окреслена проблема знайшла своє відображення у психології праці й інженерній психології (Ф. Іващенко, Є. Клімов, І. Мілерян, В. Моляко, С. Перепелиця, Б. Федоришин), у галузі медичної психології (В. Каган, В. Ораховський, Є. Чугунова), спортивної психології (Є. Ільїн, А. Пуні, О. Федик), музичної психології (Л. Баланчивадзе, Л. Бочкарьов, А. Востриков, М. Ганелін, Г. Коган, Н. Токіна, О. Хрущ-Рипінська). Найбільше розроблене поняття готовності в галузі педагогічної психології, а саме у процесі розкриття проблеми вдосконалення процесу вишівської (О. Абдуліна, Л. Долинська, Ю. Долинська, В. Крутецький, Н. Кузьміна, О. Мешко, О. Кулюткін, Ф. Ніколенко, В. Сластьонін, Т. Яценко), довишівської (М. Белей, П. Горностай, М. Левченко), післявишівської (О. Мороз, Т. Полякова, Т. Щербан) підготовки педагогічних кадрів, профдіагностування і профвідбору до педагогічної професії (К. Вербова, Г. Парамей, Г. Радчук).

Розглядається готовність як інтегральне особистісне утворення у низці наукових досліджень. У науковій літературі вона має різні назви: загальна (А. Деркач, А. Ісаєв, Є. Романова); довготривала готовність (М. Дьяченко, Л. Кандибович, М. Левітов); підготовленість (В. Крутецький, М. Левченко, С. Максименко, О. Мороз, А. Пуні, Т. Щербан та ін.).

Метою статті є розкриття проблеми готовності до діяльності, а саме: сутності поняття й підходів до трактування поняття психологічноїготовності; форм готовності.

Готовність окремими науковцями розглядається як складне особистісне утворення, багатопланова й багаторівнева структура якостей, властивостей та станів, які у своїй сукупності дозволяють певному суб’єктові більш-менш успішно здійснювати діяльність. Дослідники Е. Кузьмін, В. Отрут розглядають готовність як певний функціональний стан, психологічну й соціальну установку стосунків та взаємозв'язків, що характеризують поведінку особистості.

У тлумачному психологічному словнику подається таке визначення поняття готовність: стан людини, за якого вона готова взяти зиск із деякого досвіду. Залежно від типу досвіду цей стан може розумітися як відносно просте й біологічно детерміноване або як складне в когнітивному плані та у плані розвитку [1].

У психологічному словнику подається визначенняпоняття «готовність до дії» як стан мобілізації всіх психофізіологічних систем людини, що забезпечують ефективне виконання певних дій. Конкретний стан готовності до дії визначається поєднанням чинників, що характеризують різні рівні, сторони готовності: фізичну підготовленість, необхідну нейродинамічну забезпеченість дії, психологічні умови готовності. Залежно від умов виконання дії провідною може стати одна із цих сторін готовності до дії.

Готовність до того або іншого виду діяльності - це цілеспрямоване вираження 
особистості, що охоплює іiі переконання, погляди, мотиви, почуття, вольові та інтелектуальні якості, знання, навички, вміння, установки, налаштованість на певну поведінку. Така готовність досягається у процесі психологічної, професійної підготовки, є результатом всебічного розвитку особистості з урахуванням вимог, які висуваютьсяособливостями діяльності, професії.

В. Сластьонін розглядає готовність до діяльності як особливий психічний стан, наявність у суб'єкта образа структури певної дії та постійної спрямованості свідомості на його виконання. Вона включає різного роду установки на усвідомлення педагогічного завдання, моделі ймовірної поведінки, визначення спеціальних способів діяльності, оцінку своїх можливостей у їх співвідношенні з майбутніми труднощами й необхідністю досягнення певного результату [6].

Готовність до педагогічної діяльності досліджується 3 погляду об'єктивації внутрішніх характеристик, які зумовлюють сприятливу психологічну основу для успішності входження особистості у професійну роль вчителя.

Психологічна готовність - це істотна передумова цілеспрямованої діяльності, іiі регуляції, стійкості та ефективності. Вона допомагає людині успішно виконувати свої обов'язки, правильно використовувати знання, досвід, особисті якості, зберігати самоконтроль і перебудовувати свою діяльність за появи непередбачуваних перешкод.

Як чинник людської діяльності, феномен психологічної готовності визначає багато чого не тільки у фіналі, але вже на їі початку. Будь-яка діяльність починається із психологічної готовності людини її почати.

Важливість психологічної готовності до початку діяльності визначається насамперед труднощами подолання психологічного бар’єра на іiі старті. За останнім (тобто бар'єром) завжди стоять сумніви й коливання, пов'язані 3 переживаннями труднощів майбутньої дії, позначається також і чинник упевненості або невпевненості у своїх силах, у вдалому або невдалому виборі часу дії тощо.

Отже, психологічна готовність забезпечує динамічне залучення людини до діяльності, так само як і подальшу надійність й ефективність усієї іiі стратегії. Суттєвим $є$ й те, що психологічна готовність $є$ універсальною передумовою ефективності не тільки будь-якої діяльності, але й інших характеристик психічної життєдіяльності людини - iї спілкування і стосунків з іншими людьми, адекватності іiі ставлення до самої себе тощо [5].

Поряд із поняттям готовність у літературі вживаються поняття підготовленість та психологічна установка.

У роботах М. Дьяченка, Л. Кандибович, О. Киричука, С. Козлова, С. Максименка, А. Пуні, С. Терещука, Т. Щербан та ін. готовність як підготовленість розглядається в безпосередньому зв'язку 3 формуванням, розвитком і вдосконаленням психічних процесів, станів, якостей особистості, необхідних для успішного виконання діяльності

Дві сторони готовності до навчання та трудової діяльності: психологічну готовність та підготовленість розглядає М. Левченко. До психологічної готовності науковець відносить: а) ідейно-політичну спрямованість; б) потребу у певній спеціальній діяльності і спеціальних знаннях, інтерес, любов до них; в) внутрішнє прийняття вимог діяльності; г) усвідомлення відповідності своїх особистих якостей вимогам діяльності; д) усвідомлену мотивацію особистих прагнень до певної спеціальності; а підготовленість передбачає: а) глибоке знання наук, певний рівень розвитку; б) підготовленість у певній галузі знань; в) обізнаність у професійній діяльності, знання вимог спеціальності до особистих якостей і здібностей; г) уміння вчитися; д) морально-психологічну підготовленість. 
О. Мороз розглядає підготовленість як суттєву сторону професійної готовності молодого вчителя. Підготовленість передбачає наявність у спеціалістів конкретних знань, умінь та навичок у галузі професійної роботи і має певні ознаки: наявність таких якостей, як потреба у спілкуванні з дітьми, любов до них, широкий світогляд, наполегливість в роботі, справедливість, педагогічний такт, вимогливість до себе та інших, спостережливість, товариськість, працездатність, цілеспрямованість тощо; наявність знань, умінь та навичок у галузі навчальної, виховної роботи, підвищення кваліфікації; наявність комунікативних здібностей [7].

Психологічна установка і психологічна готовність до ефективної дії - досить близькі поняття. Психологічна установка означає відому схильність і в цьому розумінні готовність як до сприйняття, так і до дії певним чином. Готовність до ефективної дії, у свою чергу, передбачає наявність психологічної установки на досягнення очікуваного результату. Водночас ці поняття не тотожні один з одним.

Поняття психологічної готовності завжди співвідноситься 3 діяльністю й характеризується нерідко психічним станом, психічним настроєм й психологічною установкою. Однак стан психологічної готовності до ефективної діяльності постає цілісним виявом особистості й не зводиться до сукупності окремих установок.

Психологічна готовність не зводиться до установки на початок дії, але припускає ще й здатність іiі реалізації, тобто успішного здійснення. Психологічна установка полягає по своїй суті в готовності до реалізації певного й переважно заздалегідь заданого ззовні стереотипу дії.

Психологічна готовність передбачає найчастіше ламання, руйнування раніше утворених настановчих стереотипів i шаблонів внаслідок їхньої повної невідповідності новим умовам діяльності. У свою чергу кожна із психологічних установок повинна бути підкріплена відповідною їй здатністю до іiї практичної реалізації. Усе це в сукупності й може розглядатися як інтегральна характеристика психологічної готовності до ефективної дії.

Отже, психологічна готовність до сучасної ефективної діяльності містить у собі ще й готовність до випробування стресом, стресовою ситуацією на відміну від ситуації однозначної заданості установки, яка знімає цю напруженість. Окрім того, повна психологічна готовність до діяльності на відміну від однозначної установки припускає ситуацію вибору установок і способів діяльності [5].

У психолого-педагогічній літературі розглядають два основні підходи до трактування сутності психологічної готовності: функціональний та особистісний. Перший - визначає розуміння готовності до дії як стану мобілізації всіх психофізіологічних систем людини, що забезпечують ефективне іiі виконання (Н. Левітов, Г. Гаєва, Е. Ільїна, Л. Нерсесян, М. Котик). Другий підхід розглядає «психологічну готовність» як невід'ємний і суттєвий компонент розвитку особистості в цілому. Наведенорізні визначення іiі сутності: наявність здібностей (Б. Ананьєв, С. Рубінштейн), якість особистості (К. Платонов), відношення (А. Веденов), синтез властивостей особистості (В. Крутецький), особливий психічний стан особистості, який охоплює переконання, погляди, відношення, мотиви (М. Дьяченко, С. Максименко, Л. Кандибович).

Так, у дослідженнях Л.Нерсесян вивчаються функціональні стани психіки людини, які відображають феномен готовності. При цьому розрізняють довготривалу й динамічну (тимчасову, ситуативну) готовність відповідно до тривалості перебігу досліджуваного стану.

Як ситуативний психічний стан, готовність виникає у процесі розв'язання 
конкретних завдань, показуючи об'єктивні, суб'єктивні особливості та вимоги майбутньої ситуації та визначає успішність дії в конкретизований момент (Н. Левітов).

На думку М. Котика, слово «готовність» розкриває бажання і чинник ситуативності, оскільки воно сприймається більше, як характеристика якості, а не як якість особистості.

М. Дьяченко і Л. Кандибович характеризують тимчасову готовність як «стан готовності», а довготривалу - як характеристику особистості, при цьому автори підкреслюють, що довготривала й ситуативна готовності створюють функціональну єдність: тимчасова готовність - це щоразу функціональна гострота довготривалої готовності, яка підвищує іiі дієвість. Виникнення готовності як стану залежить від довготривалої готовності, у свою чергу, тимчасова визначає продуктивність довготривалої готовності в певних конкретних обставинах [3].

Є. Романова розглядає готовність до професійної діяльності на двох рівнях: загальну генералізовану особистісну готовність та «спеціальну» професійну готовність і трактує це поняття як своєрідний синтез психологічних феноменів і понять на різних рівнях становлення професіонала. На іï думку, говорячи про готовність у ракурсі професійної підготовки спеціаліста, необхідно врахувати і профпридатність суб'єктапрофесійної діяльності, його спрямованість, професійну підготовленість, його психічні стани. Профпридатність передбачає оцінку рівня розвитку психічних функцій i професійних здібностей, доповнення їх спеціальними знаннями й особистим досвідом разом із розвитком загальної системи регуляції діяльності, формуванням систем цінностей; дозволяє говорити про підготовленість професіонала; сформованість систем мотивації й управління психічним станом приводить до оцінки готовності професіонала до виконання конкретного і професійного завдання [7].

Готовність до певного виду діяльності, як зазначали М. Дьяченко та Л. Кандибович, - «це цілеспрямований вияв особистісних властивостей людини, зокрема і переконань, поглядів, мотивів, почуттів, вольових та інтелектуальних якостей, знань, навичок, вмінь, установок; така готовність є результатом ідейної, морально-політичної, психологічної професійної та фізичної підготовки» [3].

Розглядаючи складні види діяльності, автори виокремлюють ті елементи, які лежать в основі готовності до їх здійснення, а саме:

- осмислення своїх потреб, вимог суспільства, колективу або завдань, поставлених іншими людьми;

- усвідомлення цілей, реалізація яких забезпечить розв'язання окресленого завдання;

- осмислення й оцінка умов, за яких здійснюватимуться майбутні дії, актуалізація досвіду, пов'язаного в минулому з виконанням завдань і вимог подібного характеру;

- визначення на основі досвіду й оцінки обгрунтованих умов діяльності найбільш вірогідних способів розв'язання завдань або дотримання вимог;

- прогнозування перебігу своїх інтелектуальних, емоційних, мотиваційних i вольових процесів, оцінка співвідношення власних можливостей, рівня домагань і ступеня досягнення певного результату;

- мобілізація сил відповідно до мотивів праці та завдань, використання самонавіювання в процесі досягнення цілей.

Отже, ми бачимо, що в літературі не подається єдиного визначення поняття психологічної готовності, більше того, окреслене поняття близьке до таких понять, як підготовленість і психологічна установка, водночас ці поняття не ототожнюються. 
Поняття психологічної готовності розглядається 3 позиції двох підходів: функціонального й особистісного; і у свою чергу виокремлюються такі форми психологічної готовності як тимчасову й довготривалу.

Однак, незважаючи на різні підходи щодо визначення розглядуваного феномену, більшість авторів дотримується думки, що це особливе психічне явище - насамперед цілісний вияв особистості, її психічних процесів і станів 3 одного боку, а також психічних утворень і властивостей особистості з іншого.

Отже, здійснений теоретичний аналіз проблеми психологічної готовності до діяльності розгортає перспективи для подальшого дослідження впливу психологічної готовності до взаємодії вчителя з батьками молодших школярів.

\section{Література}

1. Бродовська В. Й. Тлумачний російсько-український словник психологічних термінів / Бродовська В. Й., Грушевський В. О., Патрик І. П. - К., 2007. - 512 с. 2. Вяткин А. П. Проблема психологической готовности в экономическойдеятельности / А. П. Вяткин // Известия ИГЭА, 2006. - №3 (46). С. 97-100. 3. Дьяченко М. И. Психологические проблемы готовности к деятельности / М. И. Дьяченко, Л. А. Кандыбович. - Мн. : БГУ, 1976. - 176 с. 4. Мул С. А. Логіко-теоретичний аналіз проблеми «психологічна готовність» особистості / С. А. Мул // Проблеми сучасної психології: Збірник наукових праць КПНУ імені Івана Огієнка, Інституту психології ім. Г. С. Костюка АПН України. Вип.7. - Кам'янець-Подільський: Аксіома, 2010. - С.465-474. 5. Парыгин Б. Д. Социальная психология. Проблемы методологии, истории и теории / Б. Д. Парыгин. СПб. : ИГУП, 1999. - 592 с. 6. Сластенин В. А. Профессиональная готовность учителя к воспитательной работе: содержание, структура, функционирование / В. А. Сластенин // Профессиональная подготовка учителя в системе высшего педагогического образования: межвузовский сборник научных трудов. - М. : МГПИ им. В. И. Ленина, 1982. - С. 14-28. 7. Чорна І. М.Формування психологічної готовності майбутнього вчителя до профорієнтаційної роботи у школі: дис. ... канд. псих. наук: 19. 00. 07. «Педагогічна та вікова психологія»/ Чорна Ірина Михайлівна. - Т., 2003. 